Vol.45, n. 4 : pp. 419-422, December 2002

ISSN 1516-8913 Printed in Brazil

BRAZILIAN ARCHIVES OF BIOLOGY AND TECHNOLOGY

AN INTERNATIONAL JOURNAL

\title{
Dimethoate Degradation in Plants and During Processing of Yerba Maté Leaves
}

\author{
Miguel E. Schmalko ${ }^{1 *}$, Laura A. Ramallo ${ }^{1}$, Darío Ferreira ${ }^{1}$ and Rubén D. Berlingheri ${ }^{2}$ \\ ${ }^{1}$ Centro de Investigación y Desarrollo Tecnológico(CIDeT); Facultad de Ciencias Exactas; Químicas y Naturales; \\ Universidad Nacional de Misiones; Felix de Azara 1552; 3300 Posadas - Misiones - Argentina. ${ }^{2}$ Instituto \\ Nacional de Tecnología Agropecuaria - Cerro Azul - Misiones - Argentina
}

\begin{abstract}
The objective of this research was to study degradation kinetics of dimethoate in plants of Ilex paraguariensis Saint Hilaire (or yerba maté) and during its processing. To determine dimethoate concentration, a capillary gas chromatography technique with a mass selective detector was used. Half-life times in plants ranked between 9.8 and 11.8 days. During processing, with a blanching and two drying steps, dimethoate concentration decayed to a $22.7 \%$ of its initial value (in dry basis); while during seasoning step (at $45^{\circ} \mathrm{C}$ ), half-life time was 17.3 days. With these values, preharvest safety interval was determined.
\end{abstract}

Keywords: Dimethoate, pesticide, degradation, processing, Ilex paraguariensis, yerba maté

\section{INTRODUCTION}

Dimethoate is an organophosphorus pesticide of direct application used in yerba maté (or Ilex paraguariensis Saint Hilaire) culture to control a psyllid, its principal pest. In general, degradation rates depend on the type of plants, climatic conditions and its later processing. Degradation rate determination is very useful to know what concentration the pesticide will have in the final product.

Yerba maté is a plant cultivated in the central region of South-America, with sub-tropical climate. From its leaves (once processed) a widely consumed tea in the region and in the Middle East is prepared. In Argentina, the daily average consumption per inhabitant is $20 \mathrm{~g}$; but in some regions this value is, in adults, approximately $100 \mathrm{~g}$. Its processing consists of a high heat treatment involving four steps: a blanching step with hot combustion gases at $500-550^{\circ} \mathrm{C}$ (of inlet temperature) and $120-200^{\circ} \mathrm{C}$ of exit temperature and a residence time of 3 minutes; two drying steps where the material is treated with hot air at $100-120^{\circ} \mathrm{C}$ of inlet temperature and $50-60^{\circ} \mathrm{C}$ of exit temperature, with a residence time of 4-5 hours; and a seasoning step in chambers at 40$60^{\circ} \mathrm{C}$ and a relative humidity of $60 \%$ during $30-40$ days. These particular work conditions make it very difficult to predict persistence of dimethoate. Dimethoate degradation in plants and during food processing was widely studied. Belal and Gomaa

\footnotetext{
* Author for correspondence
} 
(1979) studied persistence of dimetoathe in vegetable and cotton plants, and they found a halflife times ranking between 3.3 and 6.0 days. Noble (1985) found that in fruits and vegetable dips, working with controlled temperature $\left(25-50^{\circ} \mathrm{C}\right)$ and $\mathrm{pH}$, half life times widely ranked between some minutes and 200 days. In apricots, Cabras et al (1977.1) found half-life times ranked between 6.9 and 9.9 days in the plant, and during drying dimethoate concentration was reduced 5.3 times. These authors (Cabras et al, 1997.2) found halflife times of 4.3 days in olives; and a reduction factor of 20 during drying of raisins (Cabras et al, 1998). As it can be seen, half-life times in the plant and during food processing varied widely.

The objective of this research is to study the degradation kinetics in the plant and during processing of yerba maté. With this information, preharvest safety interval can be determined.

\section{MATERIALS AND METHODS}

\section{Material}

To study dimethoate degradation in plants of yerba maté (Ilex paraguariensis Saint Hilaire), one spray in two separated blocks was done in March 1998 and a third one in June 1998, periods in which dimethoate is normally sprayed. Only one application in each block and at the same concentration at which dimethoate is used in this culture $(5 \mathrm{~g}$ of dimethoate in $100 \mathrm{lt}$ of water, and $500 \mathrm{lt} / \mathrm{ha}$ ) was done. Applications were done in a manual form and no rain fell during the following week.

Samples were collected in a random form from different plants (approximately $500 \mathrm{~g}$ in each sample) and were maintained at low temperature ($18^{\circ} \mathrm{C}$ ) until processing. Samples were collected from day 1 to 41 after spraying. In the period of application of blocks 1 and 2, mean temperature was $22.6^{\circ} \mathrm{C}$, and during the study of block 3 , mean temperature was $16.1^{\circ} \mathrm{C}$.

To study degradation during processing, branches of the material were marked with a special paint and were processed with the other materials in a factory. Some branches were collected after blanching, another fraction was collected after the second dryer and the rest was maintained in a chamber to study degradation during seasoning.

\section{Dimethoate determination}

A Hewlett Packard (1989) technique with certain changes was used. Leaves were separated from branches and fine cut. A quantity equivalent to 20 $\mathrm{g}$ of dry leaves was weighted and then crushed in a mortar for 30 minutes, with simultaneous addition of water to complete $100 \mathrm{ml}$ (considering moisture contained in leaves). $200 \mathrm{ml}$ of acetone was added and the mixture was stirred during 10 minutes. $8 \mathrm{~g}$ of celite was added and then filtered with vacuum. The solution was put in a funnel pearshape with socket, then $20 \mathrm{~g}$ of $\mathrm{NaCl}$ was added and shaken during a few minutes. The mixture was then let to settle for an hour to separate the phases. Then, 200 $\mathrm{ml}$ of dichloromethane was added, then shaken and let setting for 12 hours. $30 \mathrm{~g}$ of $\mathrm{Na}_{2} \mathrm{SO}_{4}$ was added to the organic phase. The mixture was stirred and let settle for 20 minutes, and then filtered through glass wool (previously washed with acetone and dried in an oven) and a layer of $\mathrm{Na}_{2} \mathrm{SO}_{4} 3 \mathrm{~cm}$-thick. The filtered liquid was evaporated just to dryness in a vacuum rotary evaporator at $40{ }^{\circ} \mathrm{C}$. Then, $2 \mathrm{ml}$ of isooctane was added to the solid material and the solution was passed through a packed column with $1 \mathrm{~g}$ of silica gel 60 (mixture $\mathrm{N}^{\circ} 7734,70 / 230$ mesh).

Then, $2 \mathrm{ml}$ of toluene was added to the solid residue, and the mixture was passed through the column. Another $6 \mathrm{ml}$ of toluene were added to the column and the liquid evaporated to complete $1 \mathrm{ml}$. Then, more toluene was added to complete 2 $\mathrm{ml}$ (Fraction 1). The same operation was repeated with toluene-acetone (80/20 in volume) (Fraction 2 ), and then with acetone (Fraction 3).

Each fraction was analyzed in Hewlett-Packard Vectra 486/66xM gas chromatograph. The operating parameters were: carrier gas: helium; gas flow rate: $0.5 \mathrm{ml} / \mathrm{min}$; temperature: $234^{\circ} \mathrm{C}$ and a mass selective detector. As internal standard an $\alpha$-isomer of BHC (lindane) was used.

\section{Moisture content determination}

Moisture content was determined using the method of loss in mass at $103^{\circ} \mathrm{C}$, for 6 hours (IRAM 20503). 


\section{Recovery assay}

Untreated leaf samples were fortified with dimethoate and processed according to the dimethoate determination technique. The percent of recovery was $87.3 \%$ with a coefficient of variation of $4.2 \%$. Other authors reported recovery percentages of $73-115 \%$ (Szeto et al, 1985; Cabras et al, 1997.3; Hiskia et al, 1998).

\section{RESULTS AND DISCUSSION}

\section{Degradation in the plant}

Residues of dimethoate in the plants from blocks 1 and 2 sprayed in March 1998, and those corresponding to block 3, sprayed in June 1998, are shown in table 1.

Values of dimethoate concentration were fitted to a first order equation. Table 2 shows the pseudofirst order rates constant, the significant level of the fit and the corresponding half-life times.

When rate constants were statiscally compared, no significant difference was found. Half-life times for yerba maté were lightly higher than those found for cotton plants (between 3.3 and 6.0 days, Belal and Gomaa, 1979), apricots (between 6.9 and 9.9 days, Cabras et al, 1997.1) and olives (4.3 days, Cabras et al, 1997.2). Goodwin et al (1985) sprayed at the same concentration as the one used in the present work in strawberries, and found a higher degradation rate.

\section{Degradation during processing.}

To study degradation during processing, samples were cut 7 days after spraying. Values of dimethoate concentration after blanching and two drying steps are shown in table 3. Reduction factor of the pesticide in these steps was 4.4. In apricots, Cabras et al, (1997.1) found a reduction factor of 5.3 during drying and, the same authors (Cabras et al, 1998), found in raisins a reduction factor of 20 . The dried sample was then introduced in the seasoning chamber during 40 days, at $45^{\circ} \mathrm{C}$ and a relative humidity of $60 \%$. Dimethoate concentration at different times is shown in table 4.

When data were fitted to a first order equation, a rate constant of 0.040 day $^{-1}(\mathrm{P}=0.05)$ and a halflife time of 17.3 days was obtained. This value of half-life time is $68 \%$ higher than that found in plants.

Table 1 - Dimethoate residue ( $\mathrm{mg} / \mathrm{kg}$ of dry leaves) in different days after an application done in March 1998 (blocks 1 and 2), and in June 1998 (block 3).

\begin{tabular}{ccccc}
$\begin{array}{c}\text { Time } \\
\text { (days) }\end{array}$ & Block 1 & Block 2 & $\begin{array}{c}\text { Time } \\
\text { (days) }\end{array}$ & Block 3 \\
\hline 1 & 8.30 & 6.99 & 1 & 4.56 \\
3 & 7.17 & 5.37 & 5 & 2.26 \\
7 & 2.67 & 3.93 & 13 & 1.97 \\
15 & 2.22 & 1.71 & 20 & 1.65 \\
22 & 1.59 & 1.31 & 26 & 1.15 \\
31 & 1.39 & 0.94 & 34 & 0.24 \\
\hline
\end{tabular}

Table 2 - Pseudo first order rate constant, significative level of the fit half-life times of dimethoate degradation in the plant.

\begin{tabular}{cccc}
\hline Block & $\begin{array}{c}\text { Rate } \\
\text { constant } \\
\left(\text { days }^{-1}\right)\end{array}$ & $\begin{array}{c}\text { Significative } \\
\text { level } \\
(\mathrm{P})\end{array}$ & $\begin{array}{c}\text { Half-life } \\
\text { times (days) }\end{array}$ \\
\hline 1 & 0.059 & 0.042 & 11.8 \\
2 & 0.068 & 0.010 & 10.2 \\
3 & 0.071 & 0.011 & 9.8 \\
\hline
\end{tabular}

Table 3 - Dimethoate concentration, in $\mathrm{mg} / \mathrm{kg}$ of dry leaves after the different process steps.

\begin{tabular}{ccc}
\hline Processing step & $\begin{array}{c}\text { Concentration } \\
\pm \text { SD }\end{array}$ & $\begin{array}{c}\% \text { of the } \\
\text { enter value }\end{array}$ \\
\hline $\begin{array}{c}\text { Before } \\
\text { processing }\end{array}$ & $3.35 \pm 0.48$ & 100 \\
After blanching & $2.52 \pm 0.06$ & 75.2 \\
After drying & $0.76 \pm 0.21$ & 22.7 \\
\hline
\end{tabular}

\section{Preharvest safety intervals.}

For the material under this study, the maximum level admitted for dimethoate is $0.5 \mathrm{mg} / \mathrm{kg}$ of material. According to the results of degradation rate in plants and during processing, the preharvest safety interval is 7 days (considering a confidence limit of $95 \%$ ). With this period, the product is assured not to have higher concentration of dimethoate than the maximum one.

In some regions, the product is consumed without seasoning. In this case, the minimum period between spraying and harvest must be 22 days. 
Table 4 - Dimethoate concentration, in $\mathrm{mg} / \mathrm{kg}$ of dry leaves, during seasoning step (at $45^{\circ} \mathrm{C}$ and $60 \%$ of relative humidity)

\begin{tabular}{cc}
\hline Time (days) & Concentration \pm SD \\
\hline 0 & $0.76 \pm 0.21$ \\
12 & $0.65 \pm 0.32$ \\
15 & $0.43 \pm 0.17$ \\
28 & $0.25 \pm 0.14$ \\
40 & $<0.05$ \\
\hline
\end{tabular}

\section{CONCLUSION}

Half-life times found for dimethoate degradation in plants of yerba maté cultured in three blocks in different months of the year ranked between 9.8 and 11.8 days. Mean temperatures in these periods were 22.6 and $16.1^{\circ} \mathrm{C}$, respectively.

When the material was processed, its concentration was reduced to a $22.7 \%$ of its original value (in dry basis) in the blanching and the two drying steps, with a high heat treatment. During seasoning (at $45^{\circ} \mathrm{C}$ ), half-life time was 17.3 days, higher than that found in the plants.

According to the values of degradation rate constants in plants and during processing, the preharvest safety interval must be 7 days (in product with seasoning) and 22 days (in products consumed without seasoning). With these periods the maximum values recommended for dimethoate in this product could not be reached $(0.5 \mathrm{mg} / \mathrm{kg}$ of material).

\section{RESUMO}

O objetivo desta pesquisa foi estudar a cinética de degradação de dimetoato em plantas de erva-mate (Ilex paraguariensis Saint Hilaire) e durante o processamento destas. Para determinar a concentração de dimetoato foi empregada a técnica de cromatografia gasosa capilar, com uso de detector seletivo de massas. O tempo de meia vida nas plantas variou entre 9.8 e 11.8 dias.

Durante o processamento, com branqueamento (sapeco) e duas etapas da secagem, a concentração de dimetoato foi reduzida a $22.7 \%$ do valor inicial (base seca), enquanto que, durante $o$ estacionamento $\left(\mathrm{a} 45^{\circ} \mathrm{C}\right.$ ), o tempo de meia vida foi de 17.3 dias. Com estes valores, foi determinado o intervalo de segurança.

\section{ACKNOWLEDGMENT}

This study has been carried out with the financial support of the Foreign Trade Bureau of Misiones, Argentina. We also wish to express our special thanks to Dr. Carmen Gross.

\section{REFERENCES}

Belal, M. H. and Gomaa, E. A. A. (1979), Determination of dimethoate residue in some vegetable and cotton plants. Bull. Environm. Contam. Toxicol., 22, 726-730.

Cabras, P.; Angioni, A.; Garau, V. L.; Minelli, V.; Cabitza, F. and Cubeddu, M. (1997.1), Residues of some pesticides in fresh and dried apricots. J. Agr. Food Chem., 45, 3221-3222.

Cabras, P.; Angioni, A.; Garau, V. L.; Melis, M.; Pirisi, F. M.; Karim, M. and Minelli, V. (1997.2), Persistence of insecticide residues in olives and olive oil. J. Agr. Food Chem., 45, 2244-2247.

Cabras, P.; Angioni, A.; Garau, V. L.; Minelli, V.; Melis, M. and Pirisi, F. M. (1997.3), Pesticide in the distilled spirits of wine and its byproducts. J. Agr. Food Chem., 45, 2248-2251.

Cabras, P.; Angioni, A.; Garau, V.L.; Melis, M.; Pirisi, F.M.; Cabitza, F. and Pala, M. (1998), Pesticide residues in raisin processing. J. Agr. Food Chem., 46, 2309-2311.

Goodwin, S.; Ahmad, N. and Newell, G. (1985), Dimethoate spray residues in strawberries. J. Pest. Sci., 16, 143-146.

Hewlett-Packard. (1989), Mass Spectra Library of Pesticides. (Pesticide residue analysis in food, 6). Analytical Procedure., 11-21.

Hiskia, A. E.; Atmajidou, M. E. and Tsipi, D. F. (1998), Determination of organophosphorus pesticide residues in Greek virgin olive by capillary gas chromatography. J. Agr. Food. Chem., 46, 570-574.

IRAM 20503. (1996), Yerba Maté: Determination of loss in mass al $103^{\circ} \mathrm{C}$. Instituto Argentino de Racionalización de Materiales. Argentina.

Noble, Alan. (1985), Breakdown rates of dimethoate in fruit and vegetable dips. Pestic. Sci., 16, 349-354.

Szeto, S. Y.; Vernon, R. S. and Brown, M. J. (1985), Degradation of dimethoate and pirimicarb in asparagus. J. Agric. Food Chem., 33, 763-767.

Received: November 18, 2000; Revised: September 27, 2001; Accepted: January 18, 2002. 